UDC 574.24

LBC 20.18

\title{
FEATURES OF ADAPTATION OF LIVING ORGANISMS
}

\author{
Galina A. Sroslova \\ Volgograd State University, Volgograd, Russian Federation \\ Margarita V. Postnova \\ Volgograd State University, Volgograd, Russian Federation \\ Yuliya A. Zimina \\ Volgograd State University, Volgograd, Russian Federation
}

\begin{abstract}
The article is a literature review devoted to the study of biochemical adaptations of animals and microorganisms to changing environmental conditions. The analysis of biochemical methods for the study of adaptation mechanisms at the level of the whole organism, individual organs, enzymatic systems is important for carrying out scientific searches in the field of biochemistry, environmental medicine and other branches. Biochemical methods for studying adaptation mechanisms at the level of the whole organism, individual organs, cellular organelles and enzymatic systems are important for carrying out scientific searches in the field of biochemistry, environmental medicine and other branches. These methods determine the qualitative and quantitative identity of metabolic functions, gas exchange processes, the constancy of the intracellular environment (necessary for the functional activity of the macromolecule), and the use of available energy sources. With their help, it is possible to determine the boundaries of adaptive abilities, the phase of the impact of a factor (adaptation, predathology, pathology) and, on the basis of this, draw conclusions about the degree of resistance and sensitivity of species. Aspects of biochemical adaptation indicate that they are the key to adaptive features of living organisms to the conditions of stress, which may be various environmental factors.

Key words: adaptation, ecology, living organisms, bacteria, biochemical indicators, environment, stress, heat shock, process, "internalized" mechanisms, microorganisms, enzymes, ecological monitoring, hydrobionts, metabolism, irritants, modifiers, toxic substances, temperature.
\end{abstract}

УДК 574.24

ББК 20.18

ОСОБЕННОСТИ АДАПТАЦИИ ЖИВЫХ ОРГАНИЗМОВ

Галина Алексеевна Срослова

Волгоградский государственный университет, г. Волгоград, Российская Федерация

Маргарита Викторовна Постнова

Волгоградский государственный университет, г. Волгоград, Российская Федерация

Юлия Александровна Зимина

Волгоградский государственный университет, г. Волгоград, Российская Федерация

Аннотация. Статья представляет собой обзор литературы, посвященный исследованию биохимических адаптаций животных и микроорганизмов к меняющимся условиям окружающей среды. Анализ биохимических методов для изучения адаптационных механизмов на уровне целого организма, отдельных органов, ферментативных систем является важным для проведения научных поисков в области биохимии, экологической медицины и других отраслях. Биохимические методы для изучения адаптационных механизмов на 
уровне целого организма, отдельных органов, клеточных органелл и ферментативных систем является важным для проведения научных поисков в области биохимии, экологической медицины и других отраслях. Данные методы определяют качественное и количественное своеобразие функций обмена веществ, процессы газообмена, постоянство внутриклеточной среды (необходимое для функциональной активности макромолекулы), и использование доступных источников энергии. С их помощью можно определить границы адаптационных способностей, фазу воздействия того или иного фактора (адаптация, предпатология, патология) и на основании этого сделать выводы о степени устойчивости и чувствительности видов. Аспекты биохимической адаптации указывают на то, что они являются ключом к приспособительным особенностям живых организмов к условиям стресса, какими могут являться различные факторы окружающей среды.

Ключевые слова: адаптация, экология, живые организмы, бактерии, биохимические показатели, окружающая среда, стресс, тепловой шок, процесс, «интериоризованные» механизмы, микроорганизмы, ферменты, экологический мониторинг, гидробионты, метаболизм, раздражители, модификаторы, токсические вещества, температура.

Понимание механизмов, с помощью которых изменения окружающей среды влияют на организмы в природе представляет большой интерес для сравнительных биологов и экологов и является становится все более важным, поскольку последствия каскада изменения климата биосферы. В результате возрастает интерес к определению физиологического состояния организмов в естественном контексте [1, с. 42; 2, с. 709; 22 , с. 346]. Устойчивость организма, его адаптации к изменяющимся факторам среды остается одним из важных вопросов в биологии. Эта проблема занимает не мало важную роль в изучении многих общебиологических дисциплин, ведь она затрагивает ряд фундаментальных свойств живых организмов.

Центральное место в успехе многих из этих интегративных исследований было развитие адаптации, однако, она не всегда обсуждается в прямом виде. Часто изучение биологии начинается с обзора биологического разнообразия организмов. Как правило, рассматривается также их обитание в различных естественных условиях, что свидетельствует в пользу идеи о морфологической и биохимической адаптации к окружающей среде $[23$, с. $46 ; 26$, с. 304]. Задачи адаптации рассматривают на разных уровнях, в том числе и на экологическом.

Адаптации к условиям окружающей среды, как универсальное биологическое явление формируются и проявляются на различных уровнях биологической организации - от молекулярного до биоценотического [3, с. 26; 29 , c. 1704]. На поведенческом уровне организмы действуют обычно таким путем, который по всей видимости, увеличивает их шансы на выживание в данной среде и использование этой среды. На адаптацию могут влиять как экологические так и биохимические факторы. Экологические факторы среды оказывают на живые организмы различные воздействия, то есть могут влиять на них [4, с. 997; 27, с. 23]:

1) как раздражители - в данном случае они вызывают приспособительные изменения физиологических и биохимических функций;

2) как ограничители - обусловливают невозможность существования в данных определенных условиях;

3) как модификаторы, вызывающие морфологические и анатомические изменения организмов;

4) как сигналы, свидетельствующие об изменениях других факторов среды.

Процессы адаптации представляют основу для эволюции живых организмов. Кроме того, они являются обязательной частью индивидуального развития. Изучение приспособительных реакций организма к меняющимся условиям окружающей среды (температуpa, ионный состав, содержание кислорода и токсических веществ), является актуальным как в развитии фундаментальных представлений о механизмах биохимической адаптации, так и в коррекции патофизиологических состояний организма, которые развиваются в ответ на соответствующие изменения в окружающей среде [4, с. 998; 21, с. 54 ].

Существование микроорганизмов возможно при температуре ниже $-10^{\circ} \mathrm{C}$ и выше $+90{ }^{\circ} \mathrm{C}$. Некоторые формы бактерий выдерживают температуру $+150{ }^{\circ} \mathrm{C}$ в течение 30 мин. Некоторое время назад, учеными, работавшими в глубине ядерной свалки в Саванна-Ривер, была обнаружена колония оранжевых 
бактерий. Данный вид адаптировался к уровню радиации, который в 15 раз превышал смертельную дозу для человека. В последние годы микроорганизмы, обитающие в экстремальных условиях, находятся в центре внимания исследователей. Экстремофилы хорошо адаптированы к неблагоприятным факторам окружающей среды, обладают огромным биотехнологическим потенциалом. Как правило, их ферменты проявляют повышенную устойчивость сразу к нескольким факторам среды, что делает возможным их широкое использование в различных отраслях (например, при разработке промышленных биотехнологий) [5, с. 132; 6, с. 46]. Клетки в этих условиях начинают синтезироваться индуцибельные ферменты (их скорость синтеза изменяется в зависимости от условий существования организма). Происходит фенотипическое проявление генов, которые не проявляют серьезной активности при отсутствии лактозы в среде. У ряда других бактерий обнаружена универсальная адаптивная реакция в ответ на различные воздействия стрессового характера (например, высокие и низкие температуры, резкий сдвиг рН и др.). В этом случае адаптивная реакция проявляется в интенсивном синтезе группы сходных белков, получивших название - белки теплового шока. При стрессовых воздействиях на бактериальную клетку в ней ингибируется синтез обычных белков, но индуцируется синтез небольшой группы белков, функции которых заключаются в противодействии стрессу путем защиты важнейших клеточных структур, в первую очередь нуклеоида и мембран. Считается, что адаптивные модификации расширяют возможности организма к выживанию и размножению в более широком диапазоне условий внешней среды. Возникающие модификации могут быть относительно стабильными или, наоборот, очень неустойчивыми [3, с. 997; 5, c. 81].

Известно, что в адаптивных реакциях организма на изменение условий окружающей среды большую роль играет регуляция биохимических показателей метаболической активности, которые являются ключевыми компонентами, которые прямо или косвенно связаны с процессами, важным для выживания или размножения. Основная предпосыл- ка их использование заключается в том, что корректировки темпов физиологических процессов необходимы для метаболических процессов в соответствие с имеющимся энергоснабжением [6, с. 200; 30, с. 45]. Биохимические показатели, например, стресс, как правило, являются компонентами клеточного стрессового ответа, который усиливаются в результате воздействия условий окружающей среды, которые нарушают клеточной структуры белка. Концентрация биохимических компонентов метаболизм или сдвиг напряжений в результате изменения условий окружающей среды приводит к изменениям в синтезе белка или метаболизме, которые влияют на эффективность, роста или воспроизводства. Таким образом, измеряя биохимические показатели стресса или метаболизм могут быть использованы в качестве «моментального снимка» состояния организма на время, в которое оно было взято или собрано [24, с. $166 ; 28$, с. 79].

Временные параметры биохимической адаптации варьируют в широких пределах от длительных периодов, необходимых для эволюционного изменения аминокислотных последовательностей, до долей секунды, за которые может измениться активность уже присутствующих в клетке ферментов [7, с. 113; 8, с. 83]. Именно мгновенное изменение активности ферментов способствует восстановлению биохимических функций исследуемых бактерий при резкой смене сред обитания [9, c. $199 ; 10$, с. $9 ; 25$, с. 14$]$.

Микроорганизмы Listeria monocytogenes и Yersinia pseudotuberculosis являются возбудителями сапрозоонозов, и в процессе эволюции выработали механизмы адаптации к изменяющимся условиям среды, в том числе к температуре. «Образование ферментов с иной структурой активной поверхности, по-видимому, является стратегией организма в процессе его адаптации к изменяющимся условиям окружающей среды. Данные исследований позволяют сделать вывод, что низкая температура является фактором, обеспечивающим возбудителям сапрозоонозов независимо от степени питания конкурентоспособность при жизнеобитании в различных объектах окружающей среды, что имеет большое экологоэпидемическое значение» [11, с. 20; 12, с. 484]. 
Многие животные также обладают способностью выживать в суровых условиях Земли. Так, например, северный олень, плохо защищен от воздействия высоких температур воздуха из-за отсутствия потовых желез на большей части поверхности кожи. Кроме того, у этих животных особое поддержание высокого уровня гемоглобина в крови в течение зимнего периода: на 100 кг живого веса $-1,5$ кг гемоглобина, против 0,6-1,2 кг у других животных, а объем крови достигает $11 \%$ живого веса [13, с. 85]. Данные показатели рассматриваются как характерное приспособление, которое обеспечивает необходимый уровень жизненных процессов в суровых условиях зимнего питания.

В водной среде, в отличие от наземных условий, жизнь характеризуется большей зависимостью живых организмов от факторов среды. Поэтому водные экосистемы и их обитатели очень чувствительны к нарушению химического состава среды. Как правило, чем быстрее происходит изменение внешних условий, тем сильнее будет его воздействие на организмы. Чем большим временем располагает организм для адаптации, тем более основательно он может перестроить свои фундаментальные биохимические механизмы $[14$, c. $36 ; 15$, с. 166]. Гидробионты, как известно, являются удобными объектами при оценке степени влияния на живой организм ксенобиотиков, в том числе токсикантов, а значит, и качества среды. На водоем обычно действует целый комплекс факторов, поэтому для анализа эффектов токсикантов требуются не только модельные эксперименты, но обязательно и натурные (в условиях природных водоемов), так как, они, скорее всего, позволяют получить более объективную информацию о механизмах приспособления организмов к изменению условий среды. Биохимические методы для изучения адаптационных механизмов на уровне целого организма, отдельных органов, клеточных органелл и ферментативных систем является важным для проведения научных поисков в области биохимии, экологической медицины и других отраслях. Данные методы определяют качественное и количественное своеобразие функций обмена веществ, процессы газообмена, постоянство внутриклеточной среды (необходимое для функциональной активности макромолекулы), и использование доступных источников энергии. С их помощью можно определить границы адаптационных способностей, фазу воздействия того или иного фактора (адаптация, предпатология, патология) и на основании этого сделать выводы о степени устойчивости и чувствительности видов $[16$, с. $368 ; 17 ; 18$, c. $346 ; 19$, с. 182$]$.

Из работ Хохачка П, Сомеро Дж «Биохимические адаптации»: эти виды биохимической адаптации можно рассматривать как «интериоризованные» механизмы, отличая от других, более привычных форм биохимической адаптации, которые определяют специфику взаимодействия организма с окружающей средой. Такие «экстериоризованные» формы биохимической адаптации включают процессы определяющие защитную окраску, способность к биолюминесценции, выработку разного рода химических сигналов, химических средств защиты и нападения [17, с. 568].

Выделяют три типа адаптивных механизмов или «стратегий»: 1. Приспособление макромолекулярных компонентов клеток или жидкостей организма (изменение количества или концентрации уже имеющихся типов макромолекул; образование макромолекул новых типов, которыми замещаются макромолекулы, ранее имевшиеся в клетке). 2. Приспособление микросреды, в которой функционируют макромолекулы. 3. Приспособление на функциональном уровне, когда изменение эффективности макромолекулярных систем, в особенности ферментов, не связано с изменением числа имеющихся в клетке макромолекул или их типов. Из трех данных адаптаций складывается важное явление метаболической регуляции. Следует отметить, что между приведенными типами адаптивных систем не всегда является верным проводить границу. Часто ответ включает в себя сразу три типа адаптивных реакций $[20$, с. 270 ; 21, c. 416].

Экологические аспекты биохимической адаптации указывают на то, что они являются ключом к приспособительным особенностям живых организмов к условиям стресса, какими могут являться различные факторы окружающей среды. 


\section{СПИСОК ЛИТЕРАТУРЫ}

1. Ахмадиев, Г. М. Эколого-биологические и педагогические аспекты изучения жизнеспособности живых организмов на урбанизированных территориях России / Г. М. Ахмадиев // Научное обозрение. Педагогические науки. - 2016. - № 6. - С. 36-39.

2. Березина, Н. А. Экология растений / Н. А. Березина, Н. Б. Афанасьева. - М. : Академия, 2009.- 400 с.

3. Бузолева, Л. С. Биохимические адаптации возбудителей сапрозоонозов к факторам окружающей среды / Л. С. Бузолева, А. М. Кривошеева, Е. А. Богатыренко, М. А. Синельникова // Научное обозрение. Биологические науки. - 2015. - № 1. C. $42-43$.

4. Власова, И. Г. Клеточные механизмы адаптации к гипертермии / И. Г. Власова, И. И. Лизунова // Вестник РУДН. Серия Медицина. - 2004. № 3 (27). - С. 6-10.

5. Журавская, А. Н. Радиационная биология / А. Н. Журавская, Б. М. Кершенгольц // Радиоэкология. - 1995. - Т. 35. - № 3. - С. 706-711.

6. Зенова, Г. М. Структурно-функциональные особенности комплексов почвенных психротолерантных актиномицетов / Г. М. Зенова, М. С. Дуброва, Д. Г. Звягинцев // Почвоведение. - 2010. Т. 43. - № 4. - С. 482-487.

7. Канцерова, Н. П. Влияние тяжелых металлов на внутриклеточные $\mathrm{Ca}^{2+}$-зависимые протеиназы беспозвоночных / Н. П. Канцерова, Л. А. Лысенко, Н. Н. Немова // Актуальные проблемы биологии и экологии : Мат-лы XVI Всерос. молодежн. науч. конф., 6-10 апр. 2009, г. Сыктывкар. - Сыктывкар, 2009. - С. 81-83.

8. Кассиль, Г. Н. Внутренняя среда организма / Г. Н. Кассиль. - М. : Наука, 2003. - 227 с.

9. Конопатов, Ю. В. Основы экологической биохимии: учебное пособие: допущено Министерством сельского хозяйства РФ для студентов вузов, обучающихся по ветеринарным и биологическим специальностям / Ю. В. Конопатов. - СПб., 2017. - 136 с.

10. Косумов, Р. С. Лесные экосистемы как стабилизирующие факторы антропогенного воздействия на окружающую среду / Р. С. Косумов, М. Д. Демельханов // Молодой ученый. - 2016. № 3. - С. 415-418.

11. Левонтин, Р. К. Адаптация / Р. К. Левонтин // Эволюция. - М., 1981. - 450 с.

12. Лютая, Е. В. Хронобиологические аспекты адаптации / Е. В. Лютая // Молодой ученый. - 2016. № 3. - C. 366-370.

13. Лях, С. П. Адаптация микроорганизмов к низким температурам / С.П. Лях. - М. : Наука, 1976. $159 \mathrm{c}$.

14. Мэйнард, С. Дж. Эволюция полового размножения / С. Дж. Мэйнард. - М., 2007. - 234 с.
15. Морозкина, Е. В. Экстремофильные микроорганизмы: биохимическая адаптация и биотехнологическое применение (обзор) / Е. В. Морозкина, Э. С. Слуцкая, Т. В. Федорова, Т. И. Тугай, Л. И. Голубева, О. В. Королева // Прикладная биохимия и микробиология. -2010. - Т.46. - № 1. - С. 5-20.

16. Немова, Н. Н. Оценка состояния водных организмов по эколого-биохимическому статусу / Н. Н. Немова // Северные территории России: проблемы и перспективы развития: Материалы конференции, 23-26 июня 2008 г. - Архангельск : Институт экологических проблем Севера УрО РАН, 2008. C. 995-998.

17. Немова, Н. Н. Механизмы биохимической адаптации у водных организмов: экологические и эволюционные аспекты / Н. Н. Немова // Современные проблемы физиологии и биохимии водных организмов. Экологическая физиология и биохимия водных организмов: Сборник научных статей. - Петрозаводск : КарНЦ РАН. - 2010. - Т. 1. - С. 198-214.

18. Нечаева, И. А. Оценка микробного состояния рек Тульской области / И. А. Нечаева, Е. В. Акатова // Известия Тульского государственного университета Естественные науки. - 2014. Вып. 2. - С. 270-281.

19. Протасов, А. А. Техно-экосистема АЭС. Гидробиология, абиотические факторы, экологические оценки / А. А. Протасов [и др.] ; под ред. А. А. Протасова. - Киев : Институт гидробиологии НАН Украины, 2011. - 234 с.

20. Сапов, И. А. Неспецифические механизмы адаптации человека / И. А. Сапов, В. С. Новиков. Л. : Наука, 2004. - 146 с.

21. Сидоров, В. С. Использование интегрального биохимического индекса при определении предельно допустимых концентраций промышленных токсикантов / В. С. Сидоров, Н. Н. Немова, Р. У. Высоцкая, Ю. А. Феклов // Прикладная биохимия и микробиология. - 2002. - Т. 38. - № 3. - С. 345-350.

22. Смирнов, Л. П. Липиды в физиолого-биохимических адаптациях эктотермных организмов к абиотическим и биотическим факторам среды / Л. П. Смирнов, В. В. Богдан. - М. : Наука, 2007. $182 \mathrm{c}$.

23. Угаров, Г. С. Гипобиология. Экологические аспекты / Г. С. Угаров // Международный журнал прикладных и фундаментальных исследований. -2014. - № 10 (часть 3). - С. 166-167.

24. Урманцев, Ю. А. Природа адаптации / Ю. А. Урманцев // 1998. - № 12. - С. 34-46.

25. Хочачка, П. Биохимическая адаптация / П. Хочачка, Дж. Сомеро. - М. : Мир, 1988. $568 \mathrm{c}$.

26. Шклярук, В. Я. Адаптация человека к отрицательным воздействиям окружающей среды / В. Я. Шклярук // Вестник Тамбовского универси- 
тета. Серия: Гуманитарные науки. - 2009. - № 7(75). C. $159-164$.

27. Яблоков, А. В. Эволюционное учение / А. В. Яблоков А. Г. Юсуфов. - М. : Высшая школа, 2006. -304c.

28. Якубова, М. М. Экологические аспекты биохимической адаптации / М. М. Якубова // Известия Академик наук Республики Таджикистан (отделение биологических и медицинских наук). 2011. - № 1 (174). - C. 77-88.

29. Hastings, M. «The brain, circadian rhythms, and clock genes»// M. Hastings // Clinical review. BMJ. 1998. - №317. - pp.1704-1707.

30. Wallin, G. Impacts of Climate Change on Plant Growth, Ecosystem Services, Biodiversity, and Potential Adaptation Measure / G. Wallin Gothenburg: University of Gothenburg, 2013. -45 p.

\section{REFERENCES}

1. Akhmadiev G. M. Ecological-biological and pedagogical aspects of studying the viability of living organisms in urbanized territories of Russia, Scientific review. Pedagogical sciences, 2016, no 6, pp . 36-39.

2. Berezina N.A., Afanasyeva N.B. Jekologija rastenij. M., Akademija, 2009, $400 \mathrm{~s}$.

3. Buzoleva L. S., Krivosheeva A. M., Bogatyrenko E. A., Sinelnikova M. A. Biohimicheskie adaptacii vozbuditelej saprozoonozov $\mathrm{k}$ faktoram okruzhajushhej sredy [Biochemical adaptation of causative agents of saprozonoses to environmental factors]. Nauchnoe obozrenie. Biologicheskie nauki. [Scientific review. Biological sciences], 2015, no. 1, pp. 42-43.

4. Vlasova I. G., Lizunova I. I. Kletochnye mehanizmy adaptacii $\mathrm{k}$ gipertermii [Cell mechanisms of adaptation to hyperthermia]. Vestnik RUDN. Serija Medicina. [Bulletin of the Peoples' Friendship University. Series Medicine], 2004, № 3 (27), pp. 6-10.

5. Zhuravskaja A.N., Kershengol'c B.M. Radiacionnaja biologija [Radiacionnaja biologija]. Radiojekologija [Radiojekologija], 1995, T. 35, № 3, pp. 706-711.

6. Zenova G.M., Dubrova D.G., Zvjagincev M.S. [Strukturno-funkcional'nye osobennosti kompleksov pochvennyh psi.hrotolerantnyh aktinomicetov]. Pochvovedenie [Pochvovedenie], 2010, T. 43, № 4, pp. 482-487.

7. Kancerova N.P., Lysenko L.A., Nemova N.N. Vlijanie tjazhelyh metallov na vnutrikletochnye Sa2+zavisimye proteinazy bespozvonochnyh [The influence of heavy metals on intracellular $\mathrm{Ca} 2+$ dependent invertebrate proteinases] // Aktual'nye problemy biologii i jekologii [Actual problems of biology and ecology]: Mat-ly XVI Vseros. molodezhn. nauch. konf., 6-10 apr. 2009, g. Syktyvkar. - Syktyvkar, 2009. - pp. 81-83.

8. Kassil' G. N. Vnutrennjaja sreda organizma. M., Nauka, 2003, 227 s.

9. Konopatov Ju.V. Osnovy jekologicheskoj biohimii: uchebnoe posobie: dopushheno Ministerstvom sel'skogo hozjajstva RF dlja studentov vuzov, obuchajushhihsja po veterinarnym i biologicheskim special'nostjam. $\mathrm{SPb} ., 2017,136 \mathrm{~s}$.

10. Kosumov R.S., Demel'hano M.D. [Lesnye jekosistemy kak stabilizirujushhie faktory antropogennogo vozdejstvija na okruzhajushhuju sredu Forest ecosystems as stabilizing factors of anthropogenic impact on the environment]. Molodoj uchenyj [Young Scientist], 2016, №3, pp. 415 - 418.

11. Levontin R.K. Adaptacija .Jevoljucija, M., 1981, 450c.

12. Ljutaja E.V. Hronobiologicheskie aspekty adaptacii. Molodoj ucheny, 2016, №3, pp. 366-370.

13. Ljah S.P. Adaptacija mikroorganizmov k nizkim temperaturam. M.: Nauka, 1976. - 159p.

14. Mjejnard S. Dzh. Jevoljucija polovogo razmnozhenija M., 2007, 234p.

15. Morozkina E.V., Sluckaja Je.S., Fjodorova T.V., Tugaj T.I., Golubeva L.I., Koroljova O.V. Jekstremofil'nye mikroorganizmy: biohimicheskaja adaptacija i biotehnologicheskoe primenenie (obzor)[Extremophilic microorganisms: biochemical adaptation and biotechnological application (review)]. Prikladnaja biohimija i mikrobiologija[Applied Biochemistry and Microbiology], 2010, T.46, №1, pp. 5-20.

16. Nemova N.N. Ocenka sostojanija vodnyh organizmov po jekologo-biohimicheskomu statusu [Assessment of the state of aquatic organisms according to their ecological and biochemical status], Severnye territorii Rossii: problemy i perspektivy razvitija[Northern territories of Russia: problems and prospects]: Materialy konferencii, 23-26 ijunja $2008 \mathrm{~g}$. Arhangel'sk, Institut jekologicheskih problem Severa UrO RAN, 2008, pp. 995-998.

17. Nemova N.N. Mehanizmy biohimicheskoj adaptacii u vodnyh organizmov: jekologicheskie i jevoljucionnye aspekty. Sovremennye problemy fiziologii i biohimii vodnyh organizmov. Jekologicheskaja fiziologija i biohimija vodnyh organizmov: Sbornik nauchnyh statej- Petrozavodsk: KarNC RAN, 2010, T1, s. 198-214.

18. Nechaeva I. A. Ocenka mikrobnogo sostojanija rek Tul'skoj oblast[Evaluation of the microbial state of rivers in the Tula region]. Izvestija Tul'skogo gosudarstvennogo universiteta Estestvennye nauki [Izvestiya Tula State University Natural Sciences], 2014. Vyp. 2, - pp. 270-281.

19. Protasov A.A. Tehno-jekosistema AJeS. Gidrobiologija, abioticheskie faktory, jekologicheskie 
ocenki. pod red. A.A.Protasova. Kiev, Institut gidrobiologii NAN Ukrainy, 2011, $234 \mathrm{~s}$.

20. Sapov I.A. Novikov V.S. Nespecificheskie mehanizmy adaptacii cheloveka. L., Nauka, 2004, $146 \mathrm{~s}$.

21. Sidorov V.S., Nemova N.N., Vysockaja R.U., Feklov Ju.A. Ispol'zovanie integral'nogo biohimicheskogo indeksa pri opredelenii predel'no dopustimyh koncentracij promyshlennyh toksikantov [Use of an integral biochemical index in determining the maximum allowable concentrations of industrial toxicants]. Prikladnaja biohimija i mikrobiologija [Applied Biochemistry and Microbiology]. 2002, T. 38, № 3, pp. 345-350.

22. Smirnov L.P., Bogdan V.V. Lipidy v fiziologobiohimicheskih adaptacijah jektotermnyh organizmov $\mathrm{k}$ abioticheskim i bioticheskim faktoram sredy.M., Nauka, 2007,182 s.

23. Ugarov G.S. Gipobiologija. Jekologicheskie aspekty [Hypobiology. Ecological aspects]. Mezhdunarodnyj zhurnal prikladnyh i fundamental'nyh issledovanij[International Journal of Applied and Fundamental Research], 2014, no. 10 (chast' 3), pp. 166-167.

24. Urmancev Ju. A. Priroda adaptacii [Nature of adaptation]. Vestnik Orenburskogo gosudarstvennogo universiteta [Vestnik of the Orenburg State University], 1998, no. 2 (108), pp. 34-46.

25. Hochachka P., Somero Dzh. Biohimicheskaja adaptacija. M., Mir, 1988, 568 s.

26. Shkljaruk V.Ja. Adaptacija cheloveka k otricatel'nym vozdejstvijam okruzhajushhej sredy [Human adaptation to the negative impacts of the environment]. Vestnik Tambovskogo universiteta. Serija: Gumanitarnye nauki[Bulletin of Tambov University. Series: Humanities], 2009, pp. 159-164.

27. Jablokov A. V., Jusufov A. G. Jevoljucionnoe uchenie. M. Vysshaja shkola, 2006, 304s.

28. Jakubova M.M. Jekologicheskie aspekty biohimicheskoj adaptacii[Ecological aspects of biochemical adaptation]. Izvestija Akademik nauk Respubliki Tadzhikistan (otdelenie biologicheskih i medicinskih nauk)[Proceedings of the Academy of Sciences of the Republic of Tajikistan (Department of biological and medical Sciences)],2011, no. 1 (174), pp. 77-88.

29. Hastings M. The brain, circadian rhythms, and clock genes, Clinical review. BMJ, 1998, vol. 317, pp.1704-1707.

30. Wallin G. Impacts of Climate Change on Plant Growth, Ecosystem Services, Biodiversity, and Potential Adaptation Measure. Gothenburg, University of Gothenburg, 2013, P. 45.

\section{Information about the Authors}

Galina A. Sroslova, Candidate of biological sciences, Associate professor, Department of bioengineering and bioinformatics, Volgograd State University, prosp. Universitetskij, 100, 400062 Volgograd, Russian Federation, sroslova.galina@volsu.ru.

Margarita V. Postnova, Doctor of biological sciences, Senior researcher, Head of the department of bioengineering and bioinformatics, Volgograd State University, prosp. Universitetskij, 100, 400062 Volgograd, Russian Federation, postnova@volsu.ru.

Yuliya A. Zimina, Candidate of chemistry, Associate professor, Department of bioengineering and bioinformatics, Volgograd State University, prosp. Universitetskij, 100, 400062 Volgograd, Russian Federation,ziminaua@mail.ru.

\section{Информация об авторах}

Галина Алексеевна Срослова, кандидат биологических наук, доцент кафедры биоинженерии и биоинформатики, Волгоградский государственный университет, просп. Университетский, 100, 400062 г. Волгоград, Российская Федерация, sroslova.galina@volsu.ru.

Маргарита Викторовна Постнова, доктор биологических наук, старший научный сотрудник, заведующий кафедрой биоинженерии и биоинформатики, Волгоградский государственный университет, просп. Университетский, 100, 400062 г. Волгоград, Российская Федерация, postnova@volsu.ru.

Юлия Александровна Зимина, кандидат химических наук, доцент кафедры биоинженерии и биоинформатики, Волгоградский государственный университет, просп. Университетский, 100, 400062 г. Волгоград, Российская Федерация, ziminaua@mail.ru. 